EESTI NSV TEADUSTE AKADEEMIA TOIMETISED 1954. III kd., nr. 3

ИЗВЕСТИЯ АКАДЕМИИ НАУК ЭСТОНСКОИ ССР 1954. ТоМ III, № 3

\title{
ARHEOLOOGILISED VÄLIUURIMISED EESTI NSV-s 1953. AASTAL
}

\section{O. SAADRE}

Arheoloogilised välitööd Eesti NSV-s laienevad aastast aastasse. 1953. aasta välitööd olid peamiselt nende tööde jätkuks, mis toimusid 1952. aastal, osaliselt võeti aga uurimisele ka uusi objekte.

Uheks selliseks uueks objektiks 1953. aastal oli asulakoht Võrtsjärve looderannikul, Valma külanõukogu maa-alal, kus juba 1950. aastal oli teostatud kaevamisi $^{1}$ ja kus ENSV TA Ajaloo Instituudi arheoloogiasektori teaduslik töötaja L. Jaanits kogus materjali oma töö „Neoliitikumi mäleștusmärgid Eesti NSV territooriumil" jaoks. Asulakoht on randvalli taga $40 \times 50 \mathrm{~m}$ suurusel kõrgendikul. Läbi on kaevatud ligi pool asulakoha pindalast. Kultuurkihi paksus on keskmiselt $40-50 \mathrm{~cm}$ ja see suureneb ranna suunas. On võimalik, et rannalähedane osa asulakohast on järve vete poolt ära uhutud.

Kaevamistel avastati 2 leeaset, üks asulakoha lõunapoolsel serval, teine asula keskel. Mõlemad leeasemed olid huumusekihi alumises osas. Esimene leease oli läbimõõduga $1 \mathrm{~m}$ ja koosnes mõne sentimeetri paksusest tuhakihist, milles leidus põlenud kive. Teise leeaseme kihi paksus oli $50 \mathrm{~cm}$. ja leease ulatus pikliku süvendina puutumata pinnasesse. Süvendist leiti karu kihv, suurte loomade luid ja mõned killud keraamikat.

Leidude enamiku moodustavad tüüpilise kammkeraamika killud (joon. 1, 1). Savinõud on olnud kumerapõhjalised, valmistatud rohkesti kivipurdu sisaldavast savimassist ja võrdlemisi tugevasti põletatud. Ornament on ühtlane, koosneb kammijälgedest ja lohkudest, mis paiknevad vöötidena. Esineb aga ka teistsugust paigutust: rombe, kolmnurki või väiksematest lohukestest koostatud siksakjooni.

Suhteliselt palju oli väiksemaid tulekivist esemeid: kõõvitsaid, nuge, uuritsaid ja teravikke (joon. 1, 2).

On leitud ka hulk tulekivist noole- ja heiteodaotsi, millel on pajulehe kuju (joon. 1, 4). Lihvitud kiviesemeist on leitud väiksemaid talbu. On saadud luust esemeid, nende seas kaheosalisi liitõngi (joon. 1, 3), lihvimiskive ja merevaigust esemeid, nende seas v-kujulise auguga nööp.

Leidude hulgas esinevad üksikud nöörkeraamika killud, mida leiti kaevandi ülemises kihis. Samasugust keraamikat esineb Eesti NSV territooriumil avastatud karjakasvatajate haudades. Tõenäoliselt on siin olnud ka matmispaigad, sest ülemistes kihtides leidus inimese hambaid ja kündmisel on samalt põllult saadud karjakasvatajaile iseloomuliku kivikirve kannaosa. Need hauad on aga künniga hävitatud.

Leidude järgi otsustades kuulub Valma asulakoht III aastatuhande teise poolde e. m. a.

1 Vt. Eesti NSV Teaduste Akadeemia Toimetised 1952, I k., nr. 1, lk. 118. 
Senini Võrtsjärve ümbrusest saadud leiud pärinesid keskmisest kiviajast (Võisiku) ja I-II aastatuhandest e. m. a. (Kivisaare). Valma asulakoha leiud täiendavad senise lünga ja näitavad, et Võrtsjärve pöhjarannik on olnud pidevalt asustatud alates mesoliitikumist (keskmisest kiviajast).

Ajaloosektori juhataja, ajalooteaduste kandidaat A. Vassar jätkas kaevamisi Tallinna lähedal, Pirita jõe käärus asuval I r u linnamäel (joon. 2).

Eelnenud kaevamistega oli linnuse põhjapoolses osas kindlaks tehtud kahe põhilise kultuurkihi - vanema ja noorema - olemasolu. Noorem kultuurkiht kuulub VI-X sajandisse, kuid kamaraaluses pinnases on ka hilisemaid leide. Selle kul-
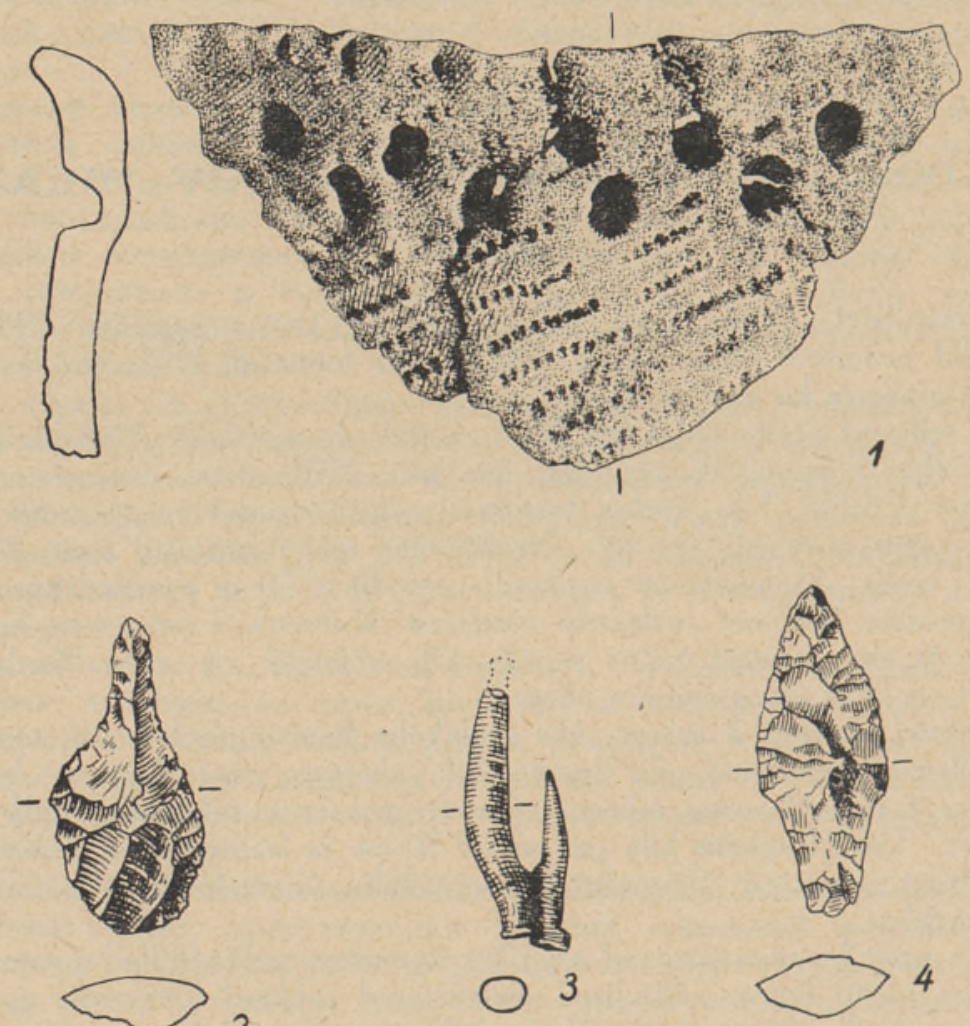

Joon. 1. Leide Valma asulakohalt: 1 - kilde kammkeraamikast; 2 - tulekivist uurits; 3 - luust liitõng; 4 - tulekivist nooleots.

tuurkihi all on steriilne liivast vahekiht ning selle all vanem kultuurkiht, mis ajaliselt kuulub esimese aastatuhande kesk- ja lõpuossa e. m. a. On uuritud ka nende kihtide ulatust. 1952. a. kaevamistel tehti kindlaks, et vanem kultuurkiht ulatub linnuse keskmise valli alla. 1953. aastal jätkati kaevamist keskmisest vallist louna pool.

Valli läänekülje juures avastati m. a. IX -X sajandisse kuuluva hoone põranda osa, mis kohati oli paeplaatidega sillutatud. Põrandal oli kividest laotud leease ja mingi kahest suuremast paeplaadist moodustatud alus, mis oli serviti kividega osaliselt äärestatud. See alus oli nagu mingiks töölauaks koduste toimingute teostamiseks. Koht sisaldas käsitsi valmistatud keraamikat, rauast naaskleid, nuge, nooleotsi, amulette ja teisi esemeid.

Steriilse liivakihi alt tuli välja ka vanem kultuurkiht. Sellest leiti leease, mille lähedal oli mitmesugust keraamikat. Osa savinõudest on kaelaosas ilustatud 


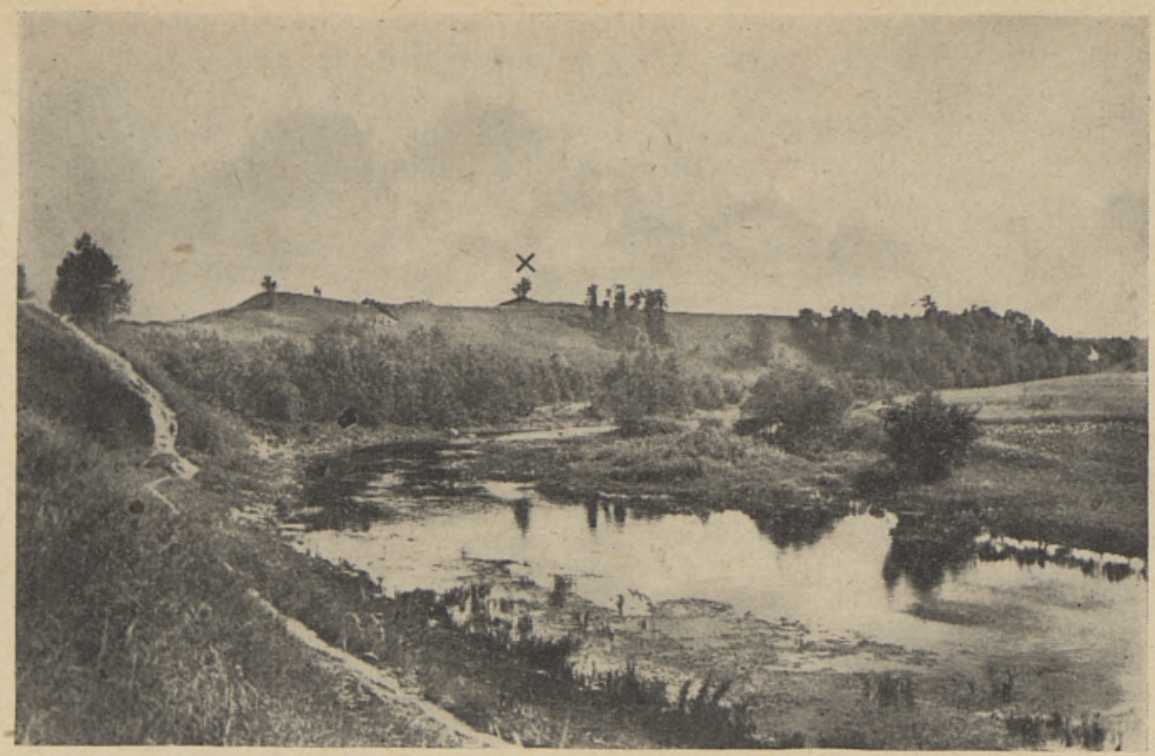

Joon. 2. Iru linnamägi. Kaevamised toimuvad keskmise valli kohal (x).
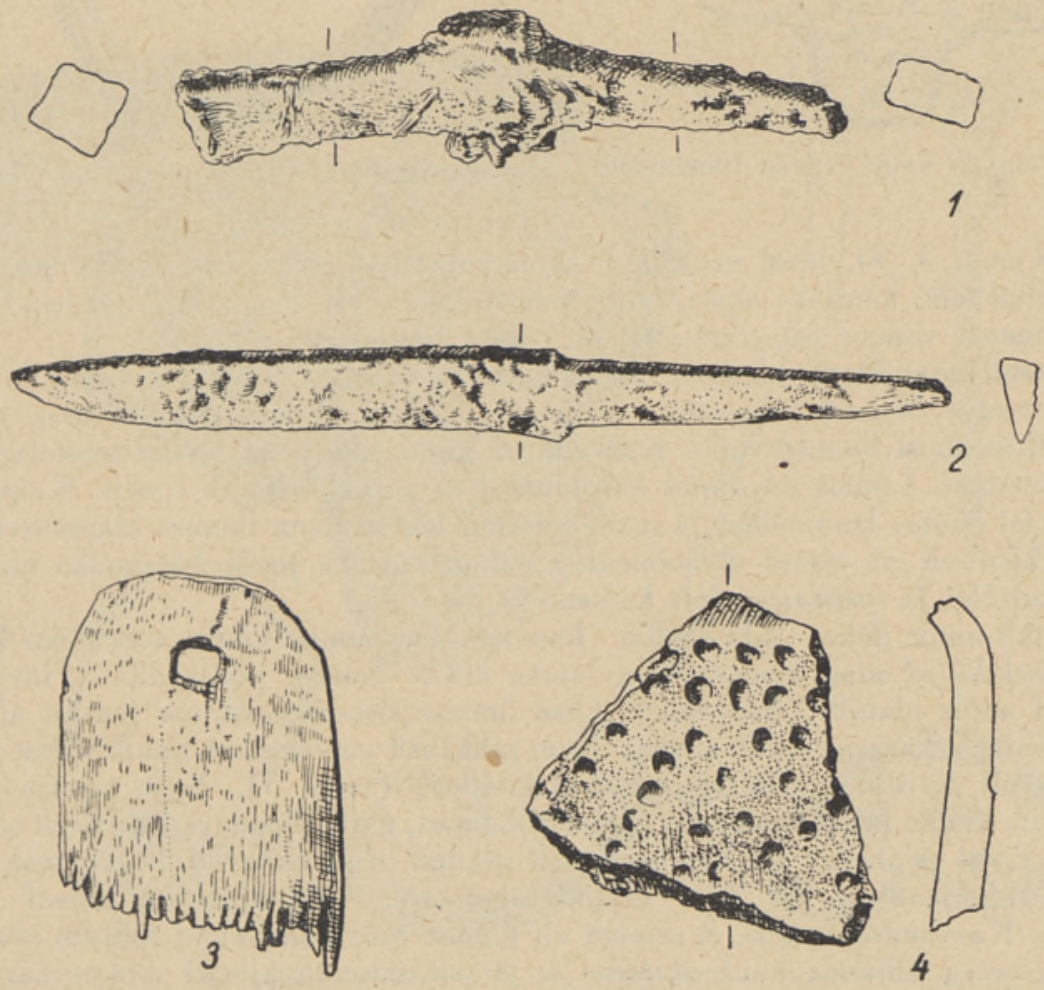

Joon. 3. Leide Rõuge linnamäelt: 1 - raudvasar; 2 - raudnuga; $3-$ luukamm; 4 - keraamika kild. 
väikeste augukeste reaga ja muist on riibitud pinnaga. Leiti veel valamisvormi tükke, luust naaskleid jne. Selle vanema kihi kaevamist jätkatakse 1954. aastal.

Arheoloogiasektori vanem teaduslik töötaja, ajalooteaduste kandidaat M. Schmiedehelm jätkas kaevamisi Võru rajooni R õ u g e linnamäel. Eelmistel aastatel oli tundma õpitud valli ehitust ja linnuse kultuurkihti ${ }^{2}$. 1953. aastal jätkati linnuse kultuurkihi uurimist. Nagu 1952. aastalgi, leiti linnuse põhjaserval eluhoone savipõranda osi. Põranda ühe osa all oli 2 leeaset, mis ilmselt kuuluvad varasemasse ehitusjärku. Suurt huvi pakuvad linnuse lōunaserval lahtikaevatud 3 suurt leeaset, mis koonusekujuliselt süvenesid pinnasesse kuni $110 \mathrm{~cm}$ sügavuseni. Uhe leeaseme juurest leiti tiiglite ja šlaki tükke, rauast nuga ja väike rauast vasarake (joon. 3, 1), mis osutab sepise tegemisele.

Omapärane leease avastati linnuse keskosas. See oli $85 \mathrm{~cm}$ sügavune, kuid seestpoolt saviga vooderdatud. Süvendi põhjas ning süvendi ümber leidus rohkesti põlenud kive ja sütt. Kivide alt leiti siledapinnalise savinõu tükke, millest oli võimalik taastada ümardatud põhjaga lame kauss. Samasugune kauss leiti ka 1952. aastal teostatud kaevamistel ${ }^{3}$. Kaevatud alalt leiti väga rohkesti, nagu juba eelmisel aastalgi, koredast kivipurruga segatud savist, samuti ka paremast savist valmistatud, augukestega ilustatud keraamikat (joon. 3, 4). Muu leitud materjali hulgas oli luust
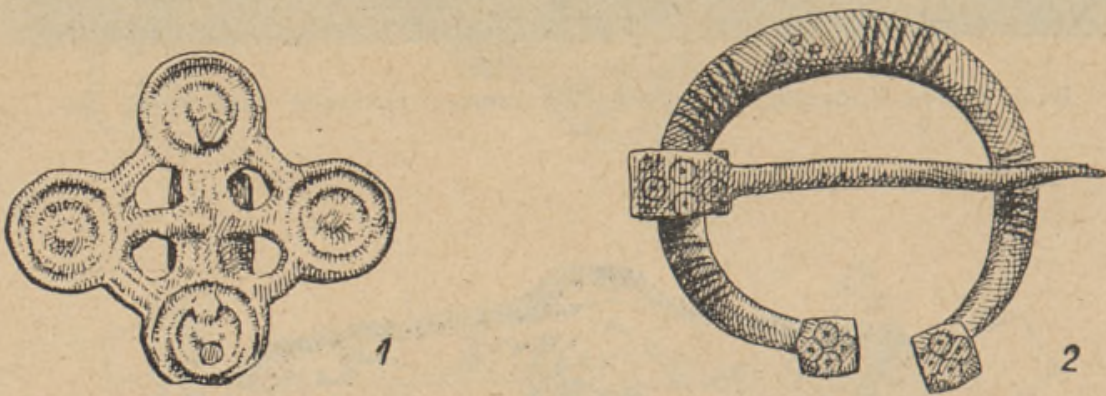

Joon. 4. Leide Naanu linnamäelt: 1 - ristpeanōela pea; 2 - hoburaudsōlg

kamm (joon. 3, 3), luust naaskleid, pronkssõrmuseid, ripatseid, luiske jne. Valli taga põllul tehti kindlakks asula, mida kaevatakse 1954. aastal. Saadud leiud kinnitavad linnuse vanuse dateerimist $\mathrm{m}$. a. I aastatuhande teise poolde.

Arheoloogiasektori juhataja; ajalooteaduste doktor $\mathrm{H}$. Moora jätkas Viljandi lähedal asuva $\mathrm{N}$ a a $\mathrm{n}$ u linnamäe uurimist. Kaevati linnuse platood ning teostati kontrollkaevamisi linnuse vallil. Kaevamised kinnitasid 1952. aastal teostatud uurimiste tulemusi. Linnus on olnud kasutamisel vaid XII sajandi kestel. Kultuurkiht oli kõikjal õhuke, keraamikat ja muid esemeid leidus enam linnuse idapoolses osas, kus tõenäoliselt on olnud eluhooneid. Leidudest võiks peale keraamika nimetada hoburaudsõlgi ja ristpeaga nõela katkendit (joon. 4).

Artikli autor jätkas O te pää linnamäe kaevamist. Uuriti sissekäiku linnuse idapoolsel küljel ning kaevati $4 \mathrm{~m}$ laiune kraav linnuse põhjavalli. Huvitavaid tulemusi andis idanõlva kaevamine. Otse linnuse sissekäiguvärava juurest algas ja kulges väikese kaarega kirde suunas $15 \mathrm{~m}$ pikkuselt suurematest raudkividest laotud tee, mis oli ääristatud püstjalt asetatud kividega (joon. 5). Selle teeraja kõrval kõrgemate kivide tasemel on pind olnud sillutatud, mida tõendavad osaliselt säilinud sillutise kivid. Vahetult sillutise kivide alt saadud leiud näitavad, et tee peaks kuuluma XII sajandisse või XIII sajandi algusesse. Kultuurkiht oli nõlval 3,8 m paksune. Kaevamisel selgus, et esialgu oli linnuse nõlva äär olnud rohkem ida pool. Linnuse serva hilisema kindlustamise ja järsustamise tagajärjel nihkus äär lääne

2 Vt. Eesti NSV Teaduste Akadeemia Toimetised, 1953. II k., nr. 1, lk. 62-64.

3 Sealsamas, lk. 63, joon. 2. 


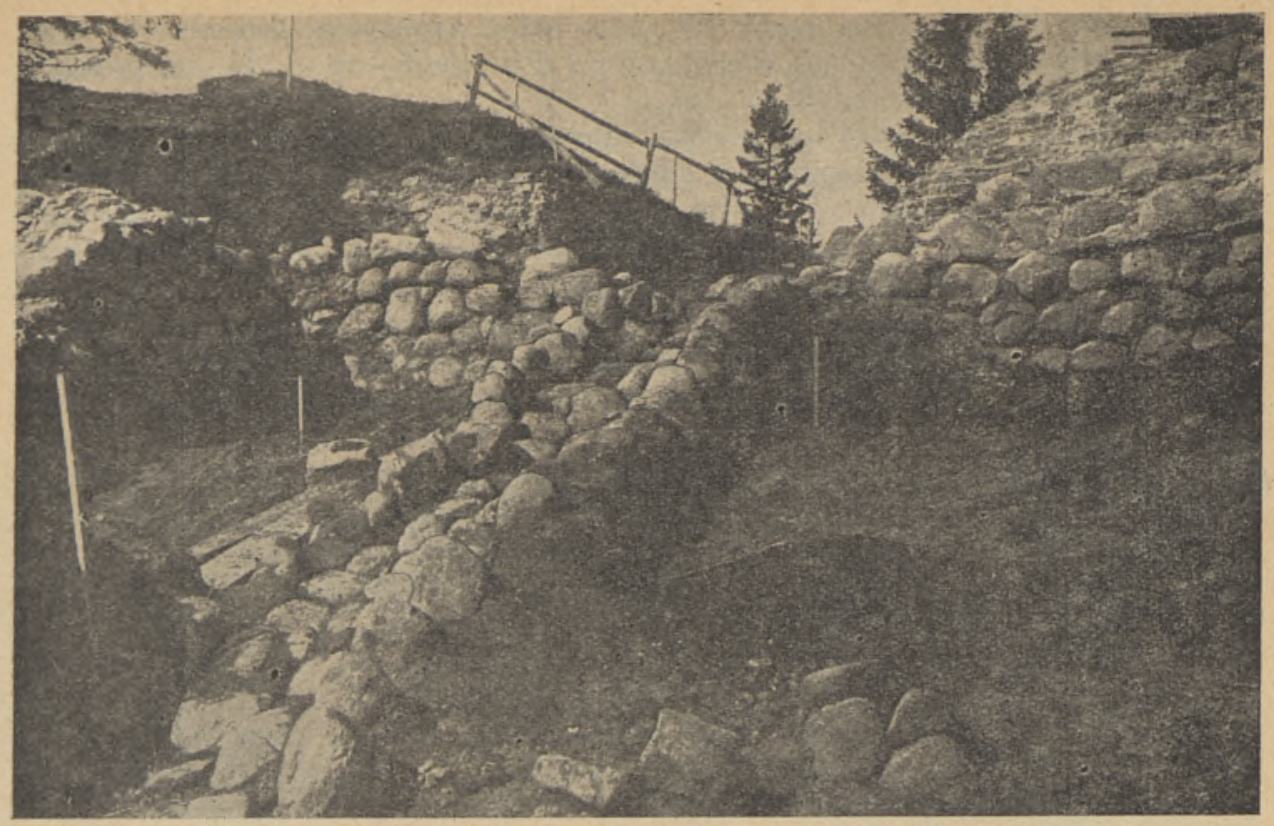

Joon. 5. Väravaeelne tee Otepää linnamäel. Vaade idast.

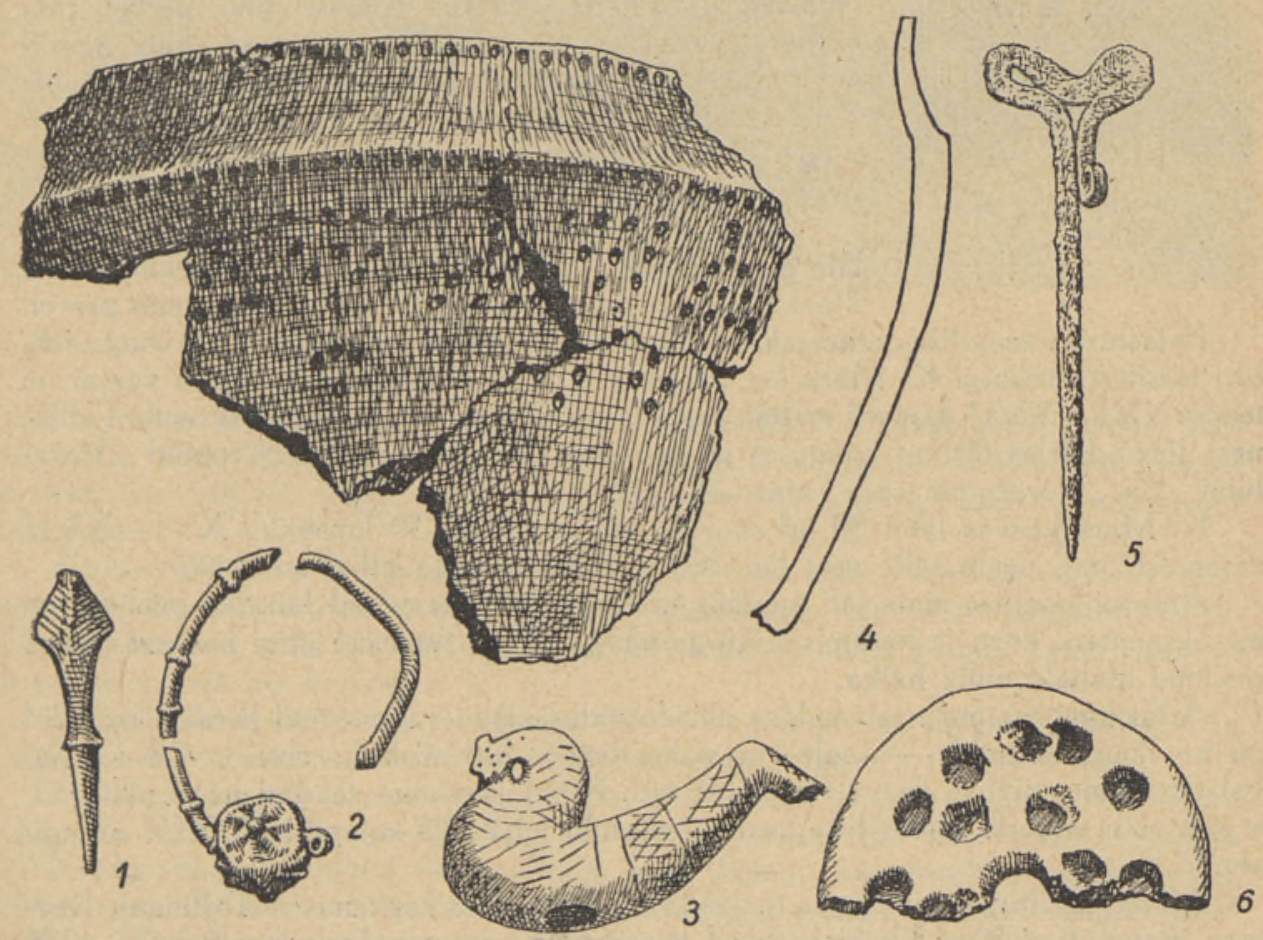

Joon. 6. Leide Otepää linnamäelt: 1 - slaavipärane nooleots; 2 - oimurōngas; 3 linnukujuline ripats; 4 - siledapinnaline lohukestega ilustatud keraamika; 5 - rauast ehtenōel; 6 - värtnakedra tükk. 
poole. Kultuurkihi ülemisest osast leiti palju kettal valmistatud keraamikat, naelu ja muid esemeid, nende hulgas slaavipäraseid nooleotsi (joon. 6,1), oimurōngaid (joon. 6, 2), käevõrusid ja lukke.

Sügavamalt saadi hulgaliselt käsitsi valmistatud koredapinnalist ja augukeste reaga ääristatud ning siledapinnalist lohukestega kaunistatud keraamikat (joon. 6, 4). Mõlemad tüübid esinevad ka Rõuges ja kuuluvad ühte ning samasse ajajärku. Peale keraamika leiti veel mitmesuguseid amulette, ripatseid (joon. 6,3 ), värtnaketri (joon. 6, 4), ehtenõelu (joon. 6, 5) jne.

Kõige sügavamas pinnase kihis oli kohati palju põlenud kive ja sütt. Tuleasemeid polnud aga võimalik eraldada. Nende põlenud kivide ja süte hulgas leidus

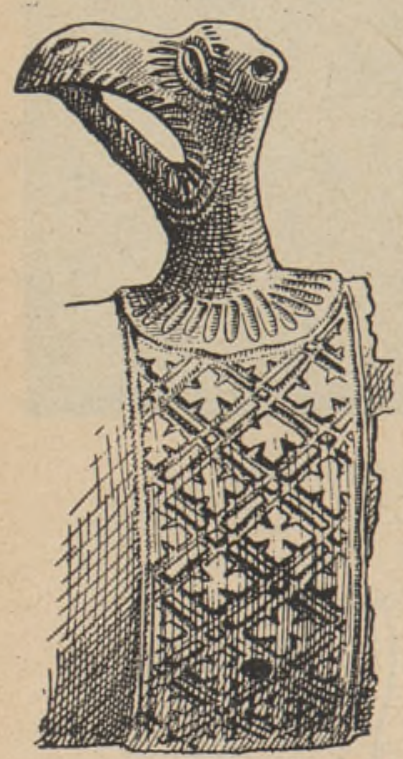

Joon. 7. Pronksplekist sōjasarve ots. kolme erineva savinõu kilde, mis kõik olid kaetud tekstiili jälgedega, - nn. tekstiilkeraamikat. Killud sarnanevad väga oma kuju, savi segu ja põletuse astme poolest Asva ja Akali hilise keraamikaga, mida on teatavasti dateeritud I aastatuhande teise poolde e. m. a.

Põhjavalli kaevamisel selgitati valli ehitust ja kaevati lahti piiskopilossi välismüür ja selles, lisaks 1952. aastal lahtikaevatule, veel 2 laskeava.

Vallist lõuna pool leiti muude esemete hulgas ka huvitav pronksplekist sõjasarv. Sarve suulisepoolne ots on murdunud, laiemas otsas on kotka pea (joon. 7). Peenemast otsast on sarve mitmel korral pronksplekiga parandatud. Välispinnal leidub kasetohu jälgi. Siiani pole korda läinud selgitada sarve päritolu.

1953. aastal püüti esmakordselt kindlaks määrata ka omaaegse Otepää aleviku asukohta. Selleks kaevati linnamäe ja Otepää kiriku vahelise nõo pervel rida proovikraave. Pikemas proovikraavis saadi hulk keraamikat XII-XIV sajandist, õmblusnõelu ja ammunoole otsi. Selles kihis kaevati välja ka puuraketega kaev (joon. 8), milles leidus tohust torba põhju ja naharibasid ning paar poolikut kingapealist.

Teiste proovikraavide kaevamisega selgitati kultuurkihi piirid. Näib, et omaaegne alevik on paiknenud umbes 2 hektari suurusel alal lääne pool linnamäge, nõo pervel.

Paleantropoloogilise materjali saamiseks Lääne-Eestist teostas arheoloogiasektori teaduslik töötaja K. Mark kaevamisi V a r b o l a linnusel, kus juba varem oli teada XVI-XVII sajandi matmispaikade olemasolu. Varbola linnus asub Tallinnast lõuna-edelas $60 \mathrm{~km}$ kaugusel $\mathrm{ja}$ on vanades vene kroonikates tuntud „Vorobiini" või „Vorobjinõi noss" nime all.

K. Mark kaevas lahti $80 \mathrm{~m}^{2}$ suuruse ala ja sai siit 50 luustikku XVI-XVII sajandist ning peale selle veel ligi 500 numbrit arheoloogilist materjali.

Antropoloogilise materjali analüüs näitas, et väljakaevatud luustike pealuud on mesokraansed, kitsa ja keskmiselt kõrge näoga. Kõigi tunnuste järgi kuuluvad need pealuud idabalti tüübi hulka.

Arheoloogilise materjali hulgas oli ülekaalus kettal valmistatud keraamika, kuid on ka muid esemeid - noole- ja viskeodaotsi, lihvimiskive, ehteid. On saadud valamisvorme, tiigleid ja valamiskopsikuid. Nüüd ja varem saadud leiud näitavad, et siin võib eeldada käsitööliste asula olemasolu juba XII sajandil või XIII sajandi algul $^{4}$.

Ajaloo Instituudi suurimaks tööks 1953. aastal olid kaevamised Tallinnas, Raekoja platsil. Kui kõigi ülalkirjeldatud kaevamiste teostamiseks kokku kulutati 4226 tööpäeva, siis Tallinnas kulutati kaevamistele 3993 tööpäeva. Nii ulatuslikke kae-

4 Vt. Eesti NSV Teaduste Akadeemia Toimetised, 1953, II k., nr. 2, Ik. 170. 
vamisi oli võimalik teostada ainult tänu suurele materiaalsele toetusele Eesti NSV Ministrite Nõukogu ja Eesti NSV Teaduste Akadeemia Presiidiumi poolt. Suurt metodoloogilist abi osutas NSV Liidu Teaduste Akadeemia Materiaalse Kultuuri Ajaloo Instituut, komandeerides oma vanema teadusliku töötaja, ajalooteaduste kandidaadi S. A. Tarakanova üheks kuuks kaevamisi juhatama. Raekoja platsi kaevamised olid nende tööde jätkuks, mis teostati Toompeal Tallinna Linnamuuseumi poolt Tallinna linna TSN Täitevkomitee initsiatiivil. Kuna need kaevamised näitasid, et Toompeal oli juba XI-XII sajandil eestlaste kindlustatud asula, siis pidid 1953. aasta kaevamised selgitama, millal on Toompea jalamile tekkinud linnataoline asula. Kaevamisteks valiti Raekoja plats sellepärast, et arhiivi andmetel pole siin ehitusi olnud juba XIII sajandist alates ja võis eeldada, et

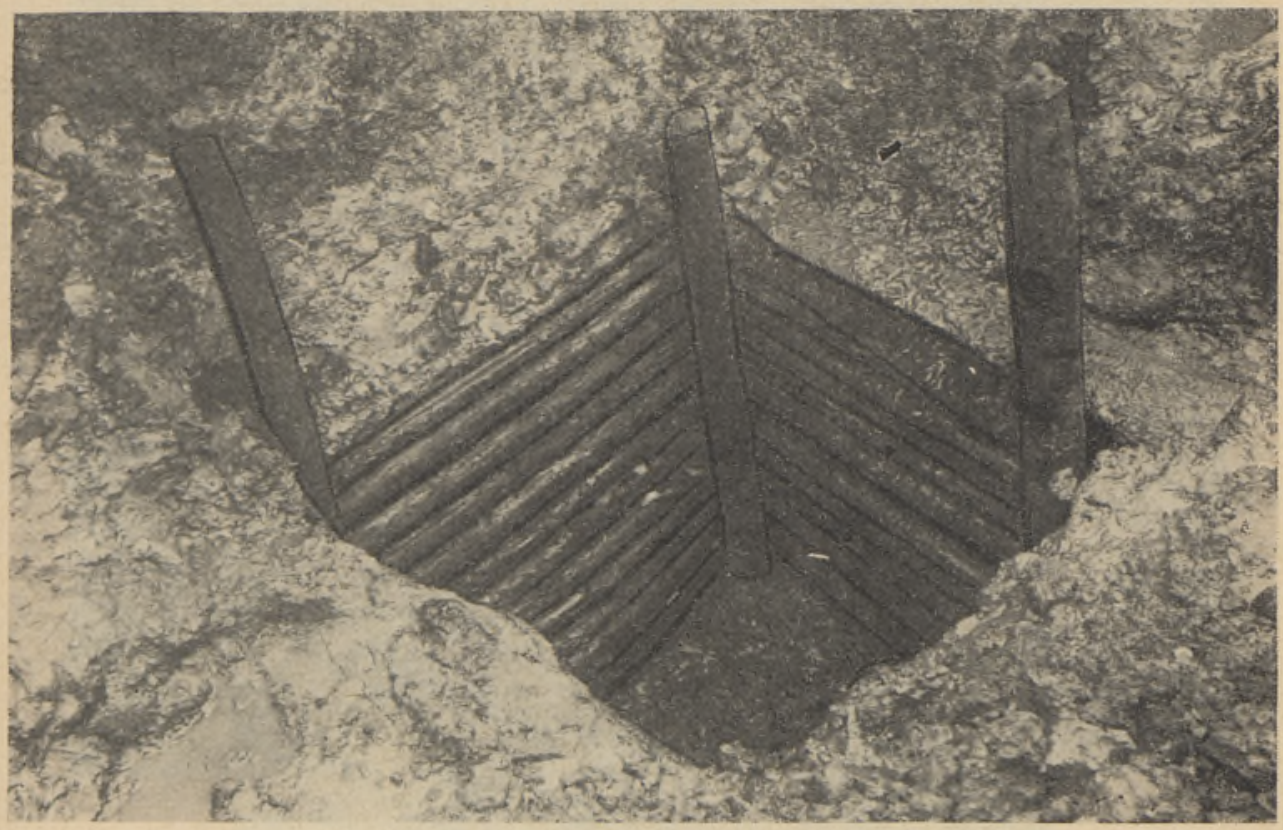

Joon. 8. Otepää asulakohal lahtikaevatud kaev.

vanim kultuurkiht on segamata. Tallinna linna TSN Täitevkomitee toetas igati instituudi tööd. Tööd algasid 4. juunil ja kestsid 8. augustini. 57 tööpäeva jooksul kaevati läbi $510 \mathrm{~m}^{2}$ pinda. Kultuurkihi paksus oli 1,9 kuni 2,1 meetrit, suurenedes ida poole.

Kultuurkihi iseloom oli oma ülemises ja alumises osas erinev nii pinnase koosseisu kui ka leiumaterjali poolest. Piiriks mõlema osa vahel võib pidada kivisillutist, mis kaevati välja $65-80 \mathrm{~cm}$ sügavusel tänavapinnast ja mis kattis peaaegu kogu kaevatava ala keskosa.

Kultuurkihi ülemise osa moodustas $30-40 \mathrm{~cm}$ paksune liivakiht, mis siia oli veetud Tallinna ümbrusest. Sellest kihist leiti muu hulgas ka tulekivist nuga.

Vahetult liiva all oli must muld, milles leidus palju paeklibu, sütt ja tellisepuru ning mis kattis paekivist sillutist. $40 \mathrm{~cm}$ sügavusel leiti kaevandi kaguosast XIX sajandisse kuulunud tänavalaterna alus. Samalt sügavuselt platsi keskosast leiti pooleldi kõdunenud postide otsad, mis olid grupeeritud teatavas kindlas järjekorrás. Võrreldes postide asetust Tallinna linnaarhiivis avastatud XVIII sajandi algusest pärineva linnaplaani eskiisiga, selgus, et need postid olid jäänused võiduväravatest, mis püstitati Peeter I auks, kui ta 1711. aastal esmakordselt Tallinna külastas. 
Ulemise kultuurkihi osa oli mitmesuguste hilisemate kaevamistega rikutud. Kihis leiti palju naelu, keraamikat, naharibasid, värtnaketru ning palju veise- ja lamba- (kitse-) luid, nagu neid määras professor V. J. Zalkin Moskvast.

Keraamika oli mitmekesine. Hilisema keraamika hulgas leidus ka varasema keraamika fragmente, mis siia olid sattunud ümberkaevamiste tagajärjel ning mis oma ornamendi ja põletusviisi poolest väga sarnanevad vana-vene keraamikaga

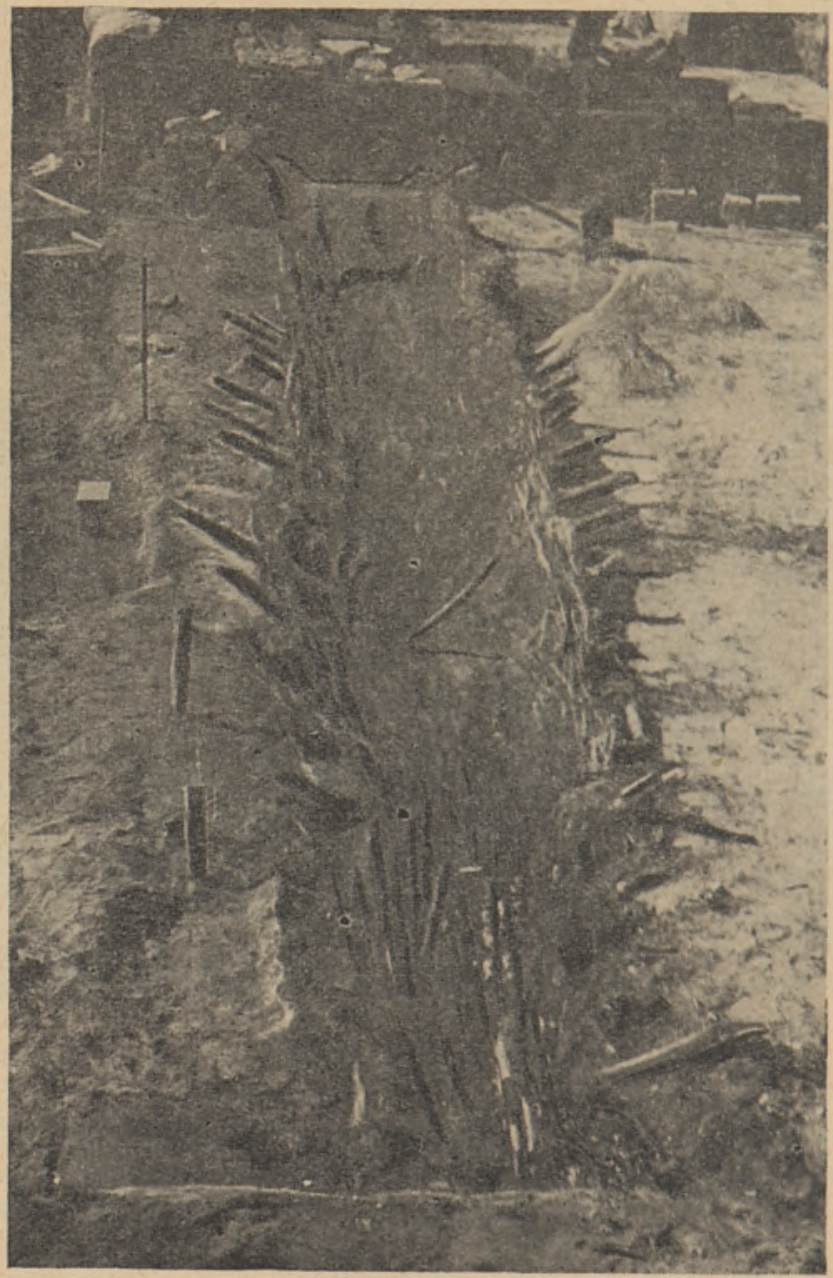

Joon. 9. Tallinnas, Raekoja platsil väljakaevatud drenaaži osa. Ristiasetatud vaiade vahe on täidetud lehtpuu okstega.

hiljemalt X sajandist ${ }^{5}$. Uldiselt aga sisaldas see kiht leide XIV-XIX sajandist.

Selle kihi all, nagu märgitud, oli tänavasillutise plaate. Nagu selgus, oli sillutist mitmes kihis üksteise peal, millede vahel oli liiva (ja selles leide). Kuna on andmeid Raekojaplatsi sillutamise kohta 1376. aastast, siis tuleb arvata, et sillutise alumised osad võivad pärineda veelgi varasemast ajast - XIV sajandi algusest. Siit leiti samuti keraamikat, muu hulgas ka Lääne-Euroopa päritoluga (Reini alalt), esemeid, mis olid tugeva põletusega, hallist savist, halli või punakaspruuni pinnaga.

5 Vt. Eesti NSV Teaduste Akadeemia Toimetised, 1953, II k., nr. 2, lk. 172-174. 
Nende põhjaosa oli sõrmedega muljutud lainelise servaga. Sellist keraamikat dateeritakse XIII-XIV sajandisse.

Sillutisekihi all oli intensiivselt must mullakiht, milles leidus söeraasukesi. Kihi paksus oli kaevandi lääneosas $40-50 \mathrm{~cm}$, idaosas üle 1 meetri. Selles kihis oli säilinud ka puukonstruktsioone.

Kaevandi edelaosas avastati juba sillutise tasemel 2 serviti teineteise peal asetsevat, lamedaks tahutud pikka männipuust planku, ja nendega rööbiti $1 \mathrm{~m}$ kaugusel samasugused plangud. Kuna nad seestpoolt olid püstpalkidega toestatud, moodustasid nad tõenäoliselt mingi veejuhtme kanali. Kanaliga risti oli maa sisse taotud vaiu, mis arvatavasti kuulusid siin asunud turu laudadele, kus kaubeldi jalatsitega

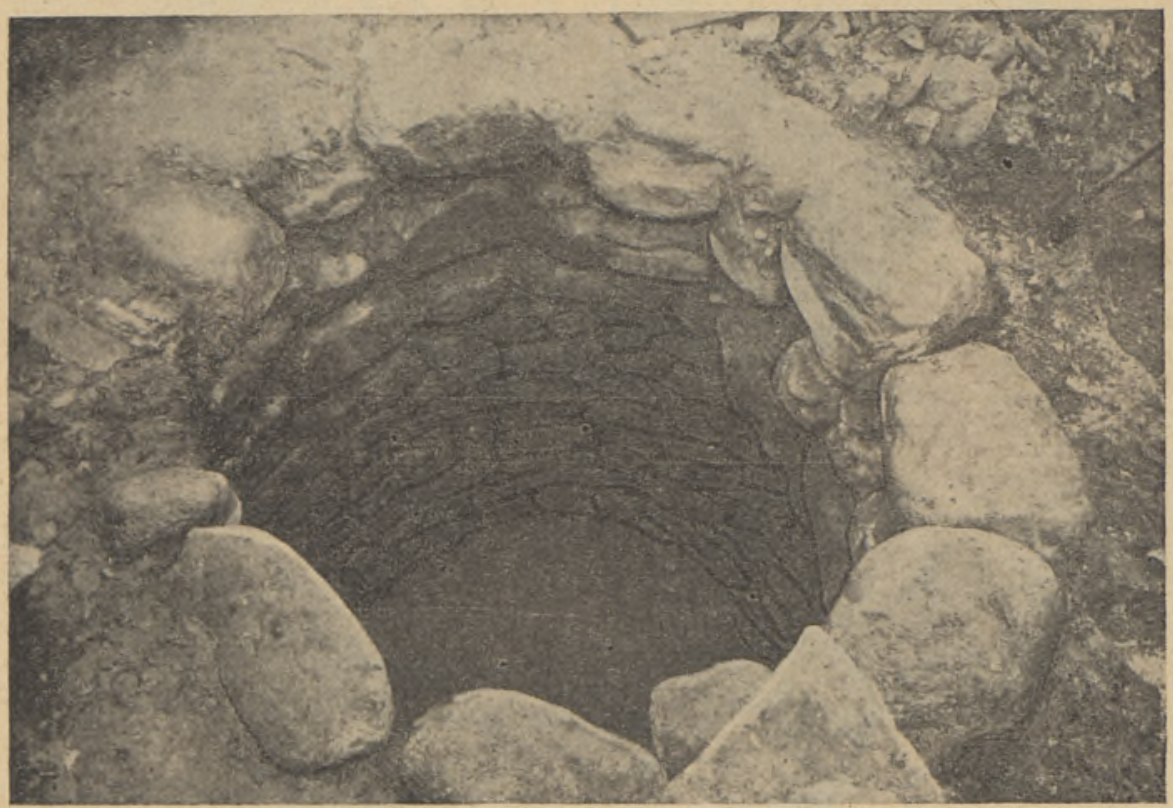

Joon. 10. Tallinnas Raekojaplatsil lahtikaevatud kaev.

ja kus neid ka parandati, nagu vöib arvata siit ümbrusest hulgaliselt leitud naharibade ja katkiste jalatsipealiste järgi.

Selle kanali all ja eemal puutumatul pinnasel leiti vastamisi poolviltu maa sisse taotud vaiade read, mille vahed olid täidetud lehtpuu (kask, lepp jne.) okstega (joon. 9). Vaiade read suundusid kaevandi keskelt radiaalselt laiali umbes Vanaturu-Kaela, Apteegi, Mundi ja Voorimehe tänava suunas, alanedes üldiselt kirde ja louna poole. Ilmselt on meil siin tegemist pinnase drenaažiga, kui arvestada, et turg asus glindieelsel niiskel platool, millest veel üle voolasid Toompea poolt tulevad veed.

Kaevandi kirdenurgas, $50-55 \mathrm{~cm}$ sügavusel XIV sajandi sillutise tasapinnast, kaevati välja kaev. Kaev oli pisut ovaalne, 1,9-2,1 m läbimõõdus, seinad olid laotud suurtest raudkividest ja vahed tihendatud samblaga. Kaev ulatus tänavapinnast $585 \mathrm{~cm}$ sügavusele ja veeseis kaevus oli umbes 2 meetrit.

Arvestades kaevu asetsemist kultuurkihis, samuti ka kaevust saadud leide pronksist hoburaudsõlgi ja käsitsi valmistatud keraamikat - võib väita, et kaev oli ehitatud XII sajandil või hiljemalt XIII sajandi algul ja tema kasutamisest oli loobutud XIII sajandil. Drenaažisüsteem on aga ehitatud hiljemalt XII sajandil.

Leidudest tuleb peale keraamika, värtnaketrade ja täringute, milledest mõned sarnanevad Gnezdovo kalmistult leitud täringutega, märkida ka hulgaliselt esine- 
nud puust esemeid (joon. 11 ja 12): lauakestest kokkupandavaid kausikesi, treitud taldrikuid ja kausse ning kamme, mis annavad tunnistust vastavate meistrite suurest oskusest. Lauakestest kokkupandavate kausikeste leide on muide saadud ka Riia linna kaevamistel XII sajandi kihist.

Leidude hulgas on huvitav puust kettake (värtna-keder), mis on ilustatud lõigatud kunstipärase paelornamendiga. Samasugust ornamendi motiivi esineb ka Novgorodis väljakaevatud puust esemeil (joon. 12, 1).

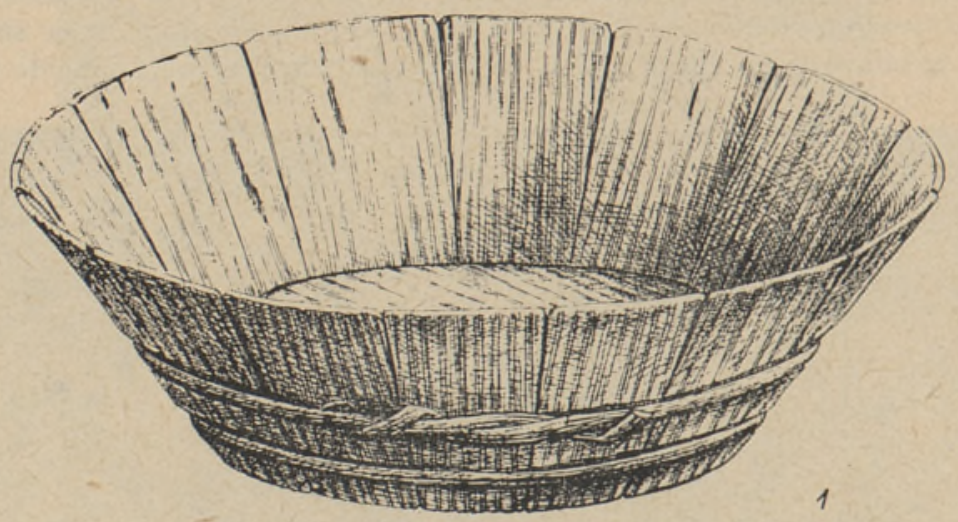

2

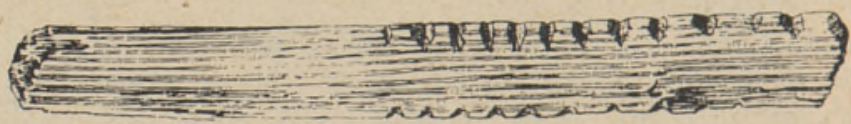

Joon. 11. Tallinnas, Raekoja platsil väljakaevatud esemeid: 1 lauakestest koosnev puunõu (rekonstr.); 2 - treitud puunõu külje tükk; 3 - arvestuspulk.

Leiumaterjal iseloomustab mitmekülgselt linnaelanike elu-olu. Kuna seda küsimust on käsitletud juba H. Moora ülevaates „,Tallinna tekkimisest ja vanusest" 6 , siis me seda siin ei puuduta. Tuleb märkida vaid asjaolu, et Raekoja plats on asula tekkimisest saadik olnud plats-turukoht oma kommunaalehitustega. Leiud ja ehitusjäänused kinnitavad veenvalt linna olemasolu siin hiljemalt XII sajandil ja linna tekkimist X sajandil.

Peale loetletud välitööde teostati A. Vassara ja $\mathrm{H}$. Moora poolt proovikaevamisi real Lääne- ja Ida-Eesti linnustel nende iseloomu ja vanuse selgitamiseks.

6 Vt. Eesti NSV Teaduste Akadeemia Toimetised, 1953, II k., nr. 2, 1k. 167-174 
A. Vassar tutvus lähemalt 14 Lääne-Eesti linnusega. Selgus, et mõnedel neist pole üldse olemas kultuurkihti, enamikul oli see aga olemas ja ajaliselt kuuluvad linnused VIII-X sajandisse.

H. Moora tutvus Ida-Eestis peamiselt Kalevipoja sängi tüüpi linnustega. Proovikaevamiste järgi otsustades näivad need linnused olevat ehitatud ja olnud kasutusel m. a. I aastatuhande teisel poolel.. Kasutuselt jäid nad ära aastatuhandete
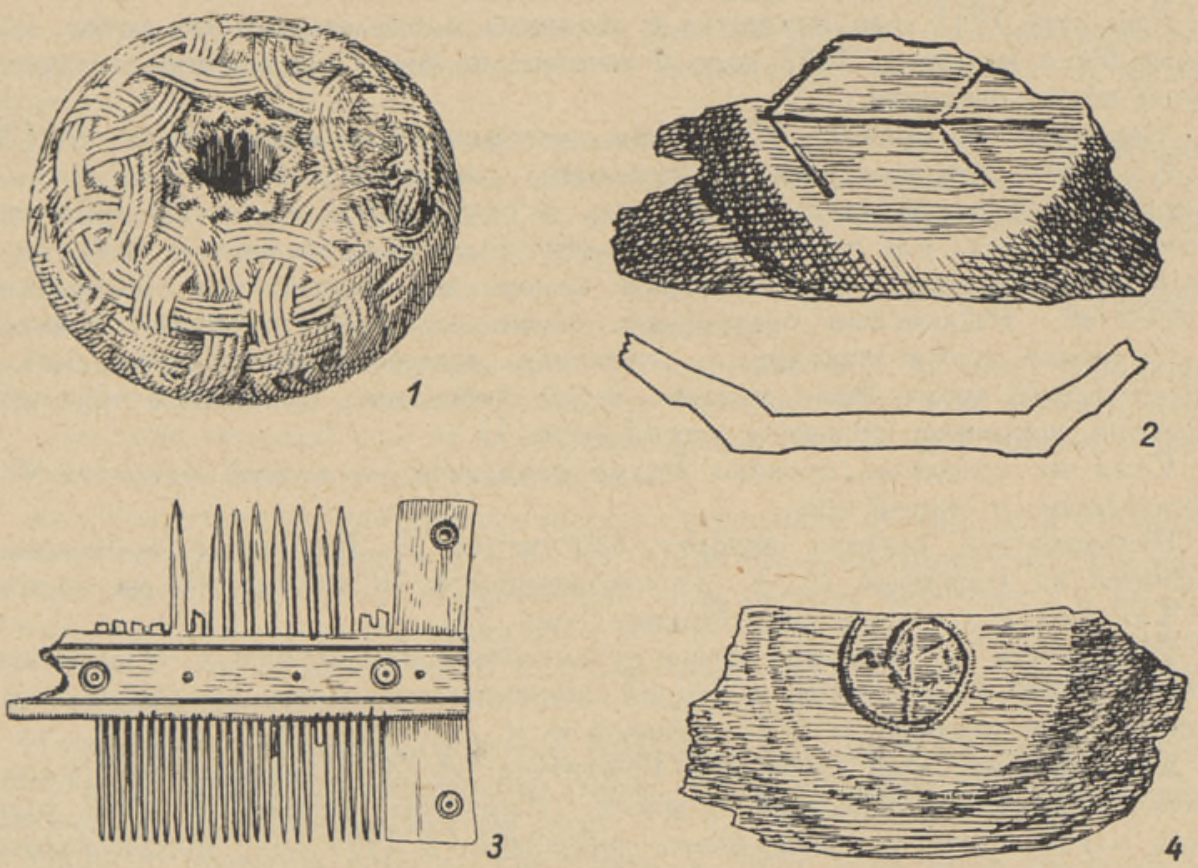

Joon. 12. Leide Tallinna Raekoja platsi kaevamistelt: $I$ - puust kettake, kaetud paelakujulise lõikeornamendiga; 2, 4 - treitud puutaldrikute põhjad; 3 - luust kahepoolse kammi katkend.

vahetuse paiku, kuigi mõned üksikud, näiteks: Alatskivi ja Saadjärve Kalevipoja sängid püsisid kasutamisel veel XIII sajandi alguseni.

Kokku võttes võib ütelda, et 1953. aasta arheoloogilised väliuurimised olid tulemusrikkad. Tänu suureulatuslikule kaevamisele Tallinnas, kus arheoloogiliste kaevamiste juures esmakordselt Eestis kasutati ka mehhanisme, saadi ühe kaevamisperioodi kestel küllaldaselt materjali Tallinna tekkimise ja vanuse küsimuse põhiliseks lahendamiseks.

Varbolast saadud antropoloogilise materjali varal läks korda kindlaks määrata ida-balti tü̈̈bi nii kaugele läände ulatuvat esinemist juba XVI-XVII sajandil.

Irus, Rõuges ja Otepääl on kindlaks tehtud linnuste kasutamise aeg ja mõnevõrra ka elanike elu-olu iseloom, kuid on veel vaja teostada suuremas ulatuses kaevamisi, et saada linnuste ehituste kohta ammendavat materjali.

Eesti NSV Teaduste Akadeemia Ajaloo Institunt

Saabus toimetusse 9. VIII 1954 


\title{
АРХЕОЛОГИЧЕСКИЕ ПОАЕВЫЕ ИССАЕДОВАНИЯ НА ТЕРРИ- ТОРИИ ӘСТОНСКОЙ ССР В 1953 ГОДУ
}

\author{
О. В. СААДРЕ
}

\section{Резюме}

Раскопки 1953 года являются в основном продолжением тех работ, которые были начаты в 1952 году и раньше, но были предприняты и некоторые новые раскопки.

Научный сотрудник Института истории Академии наук ЭССР ^. Ю. Янитс произвел раскопки поселения охотников-рыболовов на северозападном побережье озера Выртсъярв, в џентральной части Әстонии, на стоянке Валма, где первые исследования были произведены в 1950 году. Стоянка находится за береговым валом на возвышении площадью

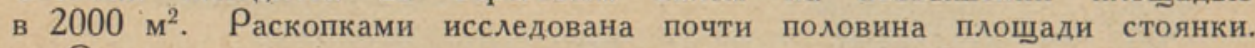

Основная масса находок - типичная ямочно-гребенчатая керамика. Сравнительно много было найдено также небольших кремневых изделий: скребков, ножичков, резцов и острий (рис. 1).

Судя по находкам, стоянка Валма относится ко второй половине III тысячелетия до нашей эры.

Руководитель сектора истории Института А. К. Вассар продолжал раскопки на городище Иру, расположенном в 10 километрах на восток от Таллина, в излучине реки Пирита (рис. 2).

Раскопками на городище были установлены два основных культурных слоя: нижний - середины и второй половины последнего тысячелетия до нашей әры и верхний - VI-X веков н. э.

Старший научный сотрудник Института М. Х. Шмидехельм продолжала раскопки на городище Рыуге, Выруского района. В 1952 году были изучены вал и часть плато городища, в 1953 году продолжалось изучение плато. Так как культурный слой этого плато в основном маломошный, достигаюший местами только 40 см, то можно надеяться завершить работу над этим городищем в ближайшие годы.

Раскопками были обнаружены остатки глиняного пола жилого помещения, очаги, много керамики преимущественно из теста с примесью крупнозернистой дресвы, обычно с дырочками по краю сосудов, и ряд других предметов (рис. 3). Городище относится ко второй половине I тысячелетия н. э.

Были продолжены также раскопки на городищах Отепяа и Наану.

Раскопками прежних лет на верхнем плато городища Отепяа были вскрыты каменные стены и главный вход епископского замка, построенного в XIII веке. Было установлено, что под развалинами средневекового замка сохранились предметы из культурного слоя әстонского городища VI-XIII веков.

В 1953 году продолжалось изучение северного и восточного вала городища. На восточном склоне была вскрыта вымощенная булыжником доpora, ведущая к главным воротам городища. Как показали предметы, найденные непосредственно под мостовой, эта дорога должна относиться к XII веку или началу XIII века (рис. 5).

Культурный слой на восточном склоне за валом оказался очень мошным - до 3,8 метров. В нижнем горизонте культурного слоя в черной углистой прослойке было обнаружено много Фрагментов текстильной керамики, по своей форме, тесту и обжигу очень напоминающей соответствующую керамику из поселений Асва и Акали. Основная масса керамики сходна с керамикой из Рыуге. 
Среди находок имеется большое количество наконечников стрел, украшений, амулетов и пр. (рис. 6), в том числе много предметов русского происхождения: височное кольџо, браслеты, Фрагмент замка киевского типа, наконечники стрел и славянская керамика.

На северном склоне была вскрыта часть крепостной стены епископского замка с бойниџами.

Впервые были произведены раскопки разведочного характера в котловине между городишем и современным городом Отепяа для обнаружения средневекового посада, упоминаемого в письменных источниках и фольклоре.

Пробными шурфами был установлен культурный слой с находками XII-XIV веков, в основном с керамикой, изготовленной на гончарном круге. Был вскрыт колодец (рис. 8), установлены приблизительно граниџы и плошадь посада - примерно в 2 га.

Руководитель сектора археологии Х. А. Моора произвел дальнейшее изучение городища Н а ану, вблизи г. Вильянди.

Как показало уже первоначальное исследование в 1952 году, городище Наану было обитаемо в течение XII века. Раскопки 1953 года подтвердили, что довольно мошный вал из песка был воздвигнут в один прием, в нем не было следов пожаров или перестройки.

Для получения палеантропологического материала из западной Әстонии научным сотрудником Института К. Ю. Марк были предприняты раскопки на городище Варбола («Воробьиный нос» русских летописей) в 60 км

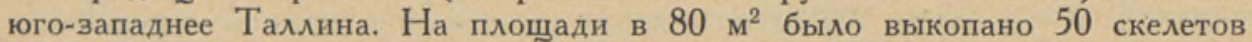
XVI-XVII вв. и, кроме того, получено более 500 номеров археологического материала.

Исследование антропологического материала показало, что черепа мезокранны, с узким и средневысоким лиџом. По всем признакам әти черепа относятся к восточнобалтийскому. типу.

Наиболее крупной работой Института в 1953 году были раскопки в Таллине на Ратушной площади.

Если все описанные выше раскопки потребовали 4226 рабочих дней, то на раскопки в Таллине было затрачено почти столько же рабочего времени (3993 рабочих дня). Эти раскопки стали возможны только благодаря большой материальной поддержке со стороны Совета Министров Әстонской ССР и Президиума Академии наук Эстонской ССР, а также благодаря методологической помощи, оказанной Институтом истории материальной культуры Академии наук СССР, откомандировавшим старшего научного сотрудника С. А. Тараканову на месяџ в Таллин для руководства раскопками.

Раскопки на Ратушной площади были продолжением исследовательских работ, начатых по инициативе Таллинского горисполкома на Тоомпеа (Вышгороде) в 1952 году. Так как раскопки 1952 года показали, что на Вышгороде уже в XI столетии существовала крепость әстонџев, то задачей работ 1953 года было установить время возникновения поселения городского типа у подножия этой крепости.

Граниџей между верхними и нижними горизонтами культурного слоя можно считать каменные вымостки, вскрытые в различных частях раскопа на глубине $65-80$ см от поверхности.

Имеются архивные данные, по которым Ратушная плошадь была вымощена в 1376 году. Судя по этому, залегавшие глубже мостовые могли быть построены еще ранее, вероятно в начале XIV века.

Находящийся под слоем каменных мостовых интенсивный черный слой земли с примесью угля достигал в западной части раскопа $40-50$ см тол- 
щины, а в восточной более 1 метра. В этом слое сохранились отдельные деревянные сооружения.

В юго-западной части раскопа уже на уровне мостовых были обнаружены два ряда уложенных параллельно плах, которые достоверно можно определить как стены водного канала. Перпендикулярно э́тому каналу были вбиты в землю сваи, которые могли принадлежать рыночным ларькам, где торговали обувью и чинили ее.

Под этим каналом, на материке, были обнаружены парные ряды наклонно вбитых в землю свай, промежуток между которыми был заполнен хворостом (рис. 9). Эти ряды свай расходились радиально в разные стороны почти из центра раскопа и представляли собой, несомненно, какую-то дренажную систему. В северо-восточном углу раскопа, на глубине 50-55 см от мостовой XIV века обнаружен колодеџ овальной формы $(1,9 \times 2,1$ м). Стенки колодџа выложены из крупных валунов путем сухой кладки. Глубина колодџа достигала 585 см от нынешней мостовой, и вода стояла в колодџе на высоте примерно 2 метров (рис. 10).

Судя по расположению колодџа в культурном слое и характеру находок в нем, он был сооружен не позднее XII или начала-XIII века, а дренажная система - не позднее XII века.

Культурный слой содержал много керамики, причем преобладала более старинная керамика, изготовленная на ручном гончарном круге, близкая к соответствующей русской керамике XI-XII веков, частично, возможно, и $\mathrm{X}$ века. Вместе с әтой посудой была найдена и лепная керамика. Помимо керамики, здесь было обнаружено много Фрагментов точеной деревянной посуды с клеймами мастеров, а может быть, и обладателей посуды, и различных размеров чашек с составными дошатыми стенками и вставными днищами (рис. 11, 12). Надо отметить, что такого же типа чашки были найдены и при раскопках города Риги в слое, датируемом XII веком.

Замечательно по своему оформлению деревянное пряслиџе (?) с плетеным орнаментом, исполненным резьбой (рис. 12, 1). Деревянные изделия с очень сходным орнаментом найдены также при раскопках в Новгороде.

Находки разносторонне характеризуют материальную культуру города позднего средневековья, а также и его предшественника, әстонского поселения городского типа.

Из всего обследованного материала явствует, что Таллин как поселение городского типа возник уже в X веке, а в XI-XII веках он был видным ремесленным и торговым џентром.

Кроме перечисленных работ, А. К. Вассар и Х. А. Моора произвели разведывательные экспедиџии с целью рекогносџировки и изучения городищ и поселений в западной и восточной Эстонии.

А. К. Вассаром было обследовано 14 городищ и поселений в разных районах западной Эстонии. Все они в основном относятся к VIII-X векам.

Х. А. Моора обследовал городища в четырех районах восточной Эстонии и установил, что городища типа «ложе Калевипоэга» относятся в основном ко второй половине $\overrightarrow{\mathrm{I}}$ тысячелетия н, э., хотя некоторые из них и существовали до XIII века.

Ннститут истории

Академии наук Эстонской ССР
Поступила в редакцию 9 VIII 1954 